\title{
PROBLEMATYKA PEDAGOGICZNA ELEMENTEM DOSKONALENIA WYKŁADOWCÓW TEOLOGII W POLSCE W LATACH 1918-1939
}

Rozwój zainteresowań pedagogicznych w środowiskach seminariów duchownych po odzyskaniu przez Polskę niepodległości w 1918 r. był wynikiem zróżnicowanej wiedzy i doświadczeń pedagogicznych wykładowców polskich wyższych seminariów duchownych. Jeszcze w okresie przedrozbiorowym w seminariach duchownych w Polsce odbywało się w zróżnicowanym zakresie kształcenie pedagogiczne. ${ }^{1}$ W trakcie zaborów pewną znajomość problematyki pedagogicznej wynieśli oni z tych form kształcenia, które były obecne pod zaborami. Przed 1918 r. polskie ziemie znajdowały się pod różnymi zaborami. Na nich od dawna funkcjonowały seminaria duchowne, które realizowały proces kształcenia duchowieństwa. Ich profesorowie zdobywali zwykle wykształcenie i doświadczenia pedagogiczne w uczelniach na terenach państw zaborczych. Ci, którzy należeli do Królestwa Kongresowego, najczęściej kształcili się w Akademii Duchownej w Petersburgu, ${ }^{2}$ a tylko niektórym udawało się zdobyć wykształcenie na zachodzie Europy. Pochodzący z zaboru pruskiego i austriackiego kształcili się najczęściej na uniwersytetach niemieckich i austrowęgierskich. ${ }^{3} \mathrm{~W}$ wolnej Polsce po 1918 r. zachodziła potrzeba integracji

1 J. K o r y c k i, Kształcenie pedagogiczno katechetyczne w polskich seminariach duchownych w rozwoju historycznym, Studia katechetyczne 4/1984, s. 221-131

2 I. W o d z i a n o w s k a, Rzymskokatolicka Akademia Duchowna w Petersburgu, Lublin 2007.

3 Por. J. K o r y c k i, Kształcenie pedagogiczno-katechetyczne w polskich seminariach duchownych w rozwoju historycznym, s. 221-261. 
środowisk seminaryjnych i ich rozwoju. Szybko zdano sobie z tego sprawę. Za zgodą biskupów polskich powołano Związek Zakładów Teologicznych im. Jana Kantego zrzeszający wykładowców seminariów duchownych i wydziałów teologicznych. Związek Zakładów Teologicznych realizował swoją misję przez dość regularnie organizowane zjazdy. W latach 1920-1939 odbyło się w Polsce osiem zjazdów Związku Zakładów Teologicznych. Podejmowały one liczne działania, aby pozszerzać wiedzę pedagogiczną i dydaktyczną swoich członków oraz inspirować to środowisko do samokształcenia w tym obszarze wiedzy.

\section{Propozycje pedagogiczne dojrzewające w Związku Zakładów Teologicznych}

Zwykle każdy zjazd Związku Zakładów Teologicznych miał własną tematykę. Jednakże uczestnicy zjazdów często zgłaszali ciekawe wnioski na zakończenie zjazdu. Niektóre z nich dotyczyły problematyki pedagogicznej. Do takich wniosków należy zaliczyć te, które zostały zgłoszone na zakończenie drugiego zjazdu z Lublinie w 1923 r. Zaproponowano, aby dla członków związku utworzyć bibliotekę z siedzibą na Katolickim Uniwersytecie Lubelskim, a członkowie Związku nadsyłali do niej swoje prace. Sugerowano także, aby w przyszłości zająć się sprawą podręczników, które mają istotną rolę $\mathrm{w}$ dydaktyce seminarium. ${ }^{4}$

Wśród zagadnień pedagogicznych podjętych na trzecim zjeździe w Łomży była również problematyka wychowania fizycznego w seminariach duchownych. Zagadnienie przedstawił ks. Walerian Adamski. Podkreślił, że troska o zdrowie przyszłych duszpasterzy wymaga zainteresowania ze strony seminarium tym zakresem wychowania. Ich dobre zdrowie będzie fundamentem, na którym będzie się budowała cała aktywność duszpasterska. Najpierw trzeba

4 Związek Zakładów Teologicznych w Polsce pod wez w a n i e m św. Ja n a K a n te g o (dalej: ZZTwP), Pamiętnik drugiego zjazdu odbytego w Lublinie 3-5.07.1923, Włocławek 1924 s. 173-174. 
alumnom uświadomić wagę zdrowia i znaczenia kultury fizycznej dla ich przyszłej pracy. Dlatego autor sugeruje, by to zagadnienie było omówione w ramach medycyny pastoralnej. Ponadto celem tego wychowania jest zaznajomienie studentów z ćwiczeniami i urządzeniami wychowania fizycznego a także metodyką tego wychowania. Autor dodaje przy tym, że należy także zwrócić uwagę na przysposobienie wojskowe. Duszpasterz powinien mieć jego ogólną znajomość i je popierać. W niektórych parafiach, gdzie nie ma inteligencji, on powinien być tym, który kształtuje właściwe zapatrywania na kulturę fizyczną. Aby cele tego wychowania mogły zostać osiągnięte, w każdym seminarium powinno być takie pomieszczenie, gdzie zachowana jest higiena, a także przygotowane miejsce do ciepłych kąpieli, sala rekreacyjna albo sala gimnastyczna, plac ćwiczeń dla co najmniej 50 osób, ogród służący do przechadzek i spacerów.

Autor podkreśla, że higieniczne życie kleryka jest podstawą zdrowia i tężyzny fizycznej przyszłego duszpasterza. Dlatego nadzwyczaj ważna jest również higiena żywienia. Intensywna nauka wymaga też higieny nauki i pracy. Dlatego autor zauważa, że wiąże się z tym konieczność planowania czasu na pracę i naukę oraz troska ze strony uczących o nieprzeciążanie ich pracą umysłową. W trakcie swego przedłożenia dodaje, że między wykładami powinny być krótkie przerwy do wykorzystania w celu krótkiego spaceru i kilku prostych ćwiczeń fizycznych. W trakcie wakacji powinno się zachęcać studentów do ćwiczeń domowych. Aby wychowanie w seminarium mogło przebiegać zgodnie z jego celami, powinien w nim być regulamin wychowania fizycznego i higieny. Nad stanem zdrowia alumnów powinien czuwać na stałe lekarz. Zaś do realizacji ćwiczeń fizycznych $\mathrm{z}$ alumnami powinien być zatrudniony wychowawca wychowania fizycznego. ${ }^{5}$ Wykład wywołał spore zainteresowanie członków zjazdu. Jedni dostrzegali trudności, wyrażali przekonanie, że zbytnie uprawianie ćwiczeń fizycznych nie da się pogodzić z formacją duchową.

5 Por. W. A d a m s k i, Wychowanie fizyczne alumnów $w$ seminariach duchownych, w: ZZTwP, Pamiętnik trzeciego zjazdu odbytego w Łomży (15-17.04.1925), Lublin 1925, s. 102-112. 
Inni natomiast zauważali, że ćwiczenia fizyczne ułatwią alumnowi panowanie nad swoim ciałem i zachowanie cnoty czystości. ${ }^{6}$

Kolejny zjazd w Łodzi odbywający się w 1929 r. sporo miejsca poświęcił problematyce pedagogicznej. Dwa referaty wygłosił na nim Karol Mazurkiewicz z Poznania. Warto dodać, że ks. Karol Mazurkiewicz w 1926 r. na Uniwersytecie we Lwowie zdobył stopień doktora habilitowanego z pedagogiki. Odtąd też w Związku Zakładów Teologicznych przez wiele lat pełnił funkcję przewodniczącego sekcji pedagogiczno-katechetycznej. Pierwszy referat przedstawiony został na forum ogólnym zjazdu. Ksiądz Mazurkiewicz mówił o przygotowaniu pedagogiczno-dydaktycznym profesorów teologii. Zwrócił w nim uwagę na potrzebę doskonalenia uczących profesorów w zakresie pedagogicznym. Każdy profesor powinien umieć usposobić pedagogicznie przyszłych kapłanów do czekającej ich pracy wychowawczej. Każdy z nich swoimi zdolnościami, wiedzą i sprawnością pedagogiczną powinien być zdolny rozbudzić zapał do pracy dydaktycznej i wychowawczej. Wszyscy profesorowie powinni dawać dobry przykład życia w wierze oraz słowem pośrednio wpływać wychowawczo. Zachęcał też, aby każdy wychowawca alumnów nie tylko studiował dzieła ascetyczne i mistyczne, ale także powinien poznać jakiś poważniejszy system pedagogiczny, zapoznać się choćby nawet ogólnie z całokształtem nauk pedagogicznych, aby orientował się w zagadnieniach pedagogicznych. W rozszerzeniu znajomości tej problematyki mogą pomóc także rozmowy czy nawet konferencje z innymi profesorami. ${ }^{7}$

Pozostali wykładowcy, zdaniem Karola Mazurkiewicza, powinni mieć także pewne zdolności pedagogiczne. Od wykładowcy przedmiotów spekulatywnych należałoby oczekiwać, by w trakcie wykładów potrafił wykorzystać okazje do wywierania wpływu wychowawczego. Może to czynić choćby przedstawiając jakąś

Tamże, s. 112-113.

7 Por. K. M a z u rk i ew i c z, Przygotowanie pedagogiczno-dydaktyczne profesorów teologii, w: ZZTwP, Pamiętnik piątego zjazdu w Łodzi 3-5.04.1929, Kielce 1929, s. 57-62. 
praktyczną wskazówkę, piękny aforyzm czy słowo zachęcające do pożądania prawdy, dobra czy piękna. W zakresie dydaktyki proponuje, by profesorowie poznali nie tylko dydaktykę naukową, ale też dydaktykę szkolną. Klerycy powinni przypatrywać się, jak profesorowie uczą a na uniwersytecie studenci powinni także uczestniczyć w wykładach z zakresu pedagogiki i dydaktyki. Ta wiedza wyniesiona z wykładów będzie dla nich podstawą do nauczania religii. Natomiast ci, którzy przygotowują się do pracy dydaktycznej na uczelniach czy w seminariach, powinni zdobyć doświadczenie dydaktyczne przez przejściowe zatrudnienie w szkolnictwie zwłaszcza średnim. Proponuje także, aby z każdej diecezji, co jakiś czas wysyłać zdolniejszych księży mających zamiłowanie do spraw pedagogicznych na studia pedagogiczne. W ten sposób można przygotować przyszłych profesorów pedagogiki i specjalistów w dziedzinie szkolnictwa. ${ }^{8}$

Na zjeździe w Łodzi w 1929 r. ks. Mazurkiewicz przedstawił w ramach sekcji pedagogiczno-katechetycznej propozycję wykładów z pedagogiki. Jego zdaniem w wykładzie powinny znaleźć się trzy zakresy treści. Pierwszym obszarem powinny być zagadnienia odnoszące się do teorii wychowawczej. Rozumie on przez nią takie zagadnienia, jak prawidłowy rozwój ciała obejmujący wychowanie fizyczne oraz prawidłowy rozwój ducha. Gdy wykład pedagogiczny odnosi się do kształtowania rozumu - powinien zawierać zagadnienia dydaktyczne, a gdy odnosi się do kształtowania woli i zdobywania cnót - będzie nazywany hodegetyką Drugim obszarem będzie praktyka wychowawcza, która obejmuje analizę szkół i ich organizacji, programów nauczania, podręczników oraz organów kierowniczych szkoły. Trzeci zakres pedagogiki w uczelniach teologicznych powinien dotyczyć historii wychowania. Aby zrealizować ten materiał K. Mazurkiewcz proponuje trzy godziny w tygodniu, czyli jedną godzinę na teorie wychowawcze, jedną na dydaktykę i jedną na historię wychowania. Poza tym ks. Mazurkiewicz zauważa, że w tym momencie nie było polskiego podręcznika pedagogiki,

8 Tamże, s. 62-64 
dlatego zarysował dość dokładnie zakres wykładów. ${ }^{9}$ Przedstawiona koncepcja wykładu została pozytywnie przyjęta przez uczestników zjazdu. Potraktowali ją jako przedstawienie koncepcji podręcznika do pedagogiki na uczelniach teologicznych.

Ksiądz Mazurkiewicz w propozycji wykładu na temat wychowania przedstawia najpierw propedeutykę wychowania, która obejmuje istotę i główne czynniki wychowania. W drugiej części proponuje zająć się procesem wychowania. Jego zdaniem, na tym wykładzie powinno się omówić „moment negatywny” wychowania polegający na czuwaniu, aby „maszyneria psychofizyczna wychowanka nie psuła się i funkcjonowała sprawnie”. Jest w nim też „moment pozytywny” obejmujący czuwanie nad tym, aby edukacja była jak najbardziej efektywna. Oznacza to troskę o właściwe wykorzystanie aktywności, zaciekawienia i zadowolenia z udanego czynu a także z zabawy. Rozbudzanie aktywności wymaga ze strony wychowawcy podsuwania wartościowego materiału wychowawczego. To zaś powinno być połączone z pouczeniami ustnymi. Ta okoliczność wymaga od wychowanka odpowiedniego nastawienia uwagi. Aby właściwie to czynić, trzeba przy tym omówić psychologiczne właściwości ludzkiej uwagi i przyczyny nieuwagi w procesie wychowania oraz dokonać analizy pilności i lenistwa w zrachowaniach wychowanka. Ksiądz Mazurkiewicz określa omówione wyżej elementy procesu wychowania nazwą ,kardynalne momenty procesu wychowawczego". ${ }^{10}$

W toku dalszego wykładu ks. Mazurkiewicz proponuje w treści przedmiotu zająć się rozwojem i zahamowaniami procesu wychowawczego. W pierwszej części zamierza przedstawić znaczenie cnoty prawdziwości i naturalności dla procesu wychowania oraz wpływ kłamstwa i grzechów pokrewnych, czyli pychy i wszelkiego udawania. Na kolejnym etapie przedmiotem zainteresowania będzie rola autorytetu w procesie wychowania. Trzeci rozdział dotyczyć będzie dążenia do piękna i wychowania estetycznego. Ostatni rozdział powinien być poświęcony nagrodom i karom w procesie wychowania.

9 Tamże, s. 237-240. 
Punkt ciężkości pracy wychowawczej spoczywa w tym procesie nie tyle na nauczaniu, ile na uszlachetnianiu i umoralnianiu wychowanka. Nabywanie wiedzy jest ważne, ale ukształtowanie człowieka jest tu najistotniejsze. Zasadniczym celem tego wychowania jest takie nastawienie wychowanka, by dążył do Boga zarówno przez rozwój życia wiary jak też przez praktykowanie zewnętrznych aktów moralnych i religijnych wypływających z jego wnętrza spontanicznie i samodzielnie. ${ }^{11}$

W dyskusji nad referatem podkreślano celność ujęcia problematyki. Jednak o. Woroniecki zwrócił uwagę, że te części wykładu pedagogicznego, określonego jako ,hodegetyka”, i użyta w nim nazwa nie są najbardziej szczęśliwe. Podkreślił, że lepiej byłoby nazwać ten przedmiot nauką o wychowaniu charakteru lub pedagogiką ścisłą. Oprócz tego o. Woroniecki dodał, że program przedstawiony przez ks. Mazurkiewicza szybko powinien przybrać formę podręcznika. Wówczas ks. Mazurkiewicz dodał, że taki podręcznik będzie się starał wydać jeszcze w 1929 r. Na zakończenie obrad sekcji przyjęto rezolucję, że ze względu na potrzebę dostarczenia wiedzy wychowawczej przyszłym nauczycielom religi należy wprowadzić do nauczania teologii wykłady z pedagogji ścisłej. Na wykłady te powinno się przeznaczyć jedną godzinę tygodniowo przez dwa lata. ${ }^{12}$ Wniosek ten był istotny, bowiem jak ustalił J. Korycki, nie wszystkie polskie seminaria $\mathrm{w}$ tym czasie miały ten przedmiot $\mathrm{w}$ swoim planie nauczania. ${ }^{13}$

$\mathrm{Z}$ upływem czasu uświadamiano sobie coraz bardziej znaczenie problematyki pedagogicznej w kształceniu teologicznym. Dlatego na zjeździe w Wilnie w 1933 r. sekcja pedagogiczno-katechetyczna podjęła bardzo istotną rezolucję. Była ona skierowana przede wszystkim do biskupów polskich. Sekcja zwracała się do biskupów o utworzenie katolickiego studium pedagogicznego w Polsce w celu kształcenia pedagogicznego, zarówno kapłanów jak i świeckich, a także

\footnotetext{
Tamże, s. 246-248.

12 Tamże, s. 248-249.

13 J. K o r y c k i, Kształcenie pedagogiczno-katechetyczne w polskich seminariach duchownych w rozwoju historycznym, s. 234.
} 
o wysyłanie młodych kapłanów na studia pedagogiczne celem przygotowania profesorów katechetyki i wizytatorów nauki religii oraz o ustalenie programu przedmiotów pedagogicznych w seminariach duchownych oraz o wyznaczenie im miejsca w siatce godzin w planie seminaryjnym. Przedstawiciele tej sekcji podkreślali, że do przygotowania pedagogiczno-katechetycznego alumna konieczne jest 6-7 godzin tygodniowo tych zajęć w planie rocznym. ${ }^{14}$ Ten apel jest wyrazem bardzo pilnej potrzeby kształcenia pedagogiczno-katechetycznego we wszystkich seminariach duchownych i na wydziałach teologicznych w Polsce.

\section{Dydaktyka akademicka}

W trakcie zjazdów Związku Zakładów Teologicznych wiele miejsca poświęcono także problematyce dydaktycznej. Z punktu widzenia uczestników trzeciego zjazdu najważniejszą sprawą była problematyka związana z dydaktyką akademicką. Dlatego problematyka dotycząca podręczników do nauczania teologii była dość obszernie dyskutowana na trzecim zjeździe w Łomży w 1925 r. Prezes Związku, ks. Piotr Kremer, najpierw poinformował o decyzji zarządu Związku Zakładów Teologicznych. Podkreślił, że zarząd będzie podejmował wysiłki sprzyjające publikowaniu w języku polskim oryginalnych polskich podręczników do studiów teologicznych albo będzie przychylał się do tłumaczenia na język polski szczególnie wartościowych dzieł zagranicznych. Najpierw postanowiono przetłumaczyć na język polski podręczniki do nauczania dogmatyki. Zdecydowano, że będzie to podręcznik Bartmana ${ }^{15}$ i Pohlego. ${ }^{16}$ Jego tłumaczeniem zajęło się środowisko Wydziału Teologicznego w Wilnie. ${ }^{17}$

14 M. S o p o ć k o, Program katechetyki w seminariach duchownych, w: ZZTwP, Pamiętnik siódmego zjazdu w Wilnie 19-21.04.1933, Wilno 1934, s. 321.

15 B. B a r t m a n n, Lehrbuch der Dogmatik, Breisgau 1932.

16 J. P o h l e, Lehrbuch der Dogmatik, Druck und Verlag von Ferdinand Schöningh, Paderborn 1907.

17 Por. W. A d a m s k i, Wychowanie fizyczne alumnów w seminariach duchownych, w: ZZTwP, Pamiętnik trzeciego zjazdu odbytego w Łomży, s. 236-237. 
Wtedy również dyskutowano nad tłumaczeniem podręcznika do patrologii. Uznaniem polskich profesorów cieszył się podręcznik autorstwa Rauschen $^{18} \mathrm{~W}$ opracowaniu Wittiga. Sekcja homiletyczno-patrologiczną opowiedziała się za tym, by nie korzystać z podręcznika patrologii przygotowanego przez Bardenhewera. ${ }^{19}$ Sugerowano nawet, aby ks. Krzeszkiewicz, jako przewodniczący sekcji homiletyczno patrologicznej, stworzył komisję do spraw podręcznika do patrologii i homiletyki. ${ }^{20}$

Kolejnym zagadnieniem wymagającym zajęcia się była problematyka aparatu naukowego dla teologii. Dydaktyka teologii wymagała wypracowania polskiej terminologii teologicznej. Długa niewola narodowa nie dała możliwości wytworzenia takiej terminologii. Dlatego taki wniosek zgłosił przewodniczący zarządu, ks. Kremer. We wniosku postulował, aby Walne Zgromadzenie Związku Zakładów Teologicznych zleciło zarządowi Związku Zakładów Teologicznych zorganizowanie komisji w celu ustalenia polskiej terminologii teologicznej. Ksiądz Leon Puciata z Wydziału Teologicznego w Wilnie rozszerzył wniosek, aby zarząd zorganizował dwie komisje ds. polskiej terminologii zarówno teologicznej jak i filozoficznej. W takiej postaci wniosek został przyjęty przez Walne Zgromadzenie. ${ }^{21}$

Przewodniczący zarządu ZZT, ks. Piotr Kremer, powrócił do sprawy organizowania biblioteki Związku wcześniej omawianej na zjeździe w Lublinie. Podkreślił, że zarząd ma trudności z jej zorganizowaniem, bowiem nie ma zbyt wielu środków na zakup nowych egzemplarzy książek, a członkowie Związku Zakładów Teologicznych nie nadsyłają swoich publikacji. W trakcie dyskusji podkreślono, że celem takiej biblioteki jest utworzenie zbioru książek, które dotyczyć

18 G. R a u s c h e n, Grundriß der Patrologie mit besonderer Berücksichtigung des Lehrgehalts der Väterschriften, Herder 1921.

19 O. B a r d e n h e w e r, Patrologie, Freiburg 1910.

20 W. A d a m s k i, Wychowanie fizyczne alumnów w seminariach duchownych, s. 237-238.

${ }^{21}$ Tamże, s. 238-239. 
będą problematyki pedagogicznej i staną się narzędziem w rozwoju pedagogicznym wykładowców teologii. ${ }^{22}$

Kolejny wniosek zgłosił ks. Henryk Betto z Łomży. Podkreślił, że należy zwrócić większą uwagę na pogłębienie wiedzy pedagogiczno-metodycznej zarówno wśród członków związku jak i nowego pokolenia wykładowców rozpoczynających pracę w seminariach duchownych. ${ }^{23}$

Czwarty zjazd, odbywający się w Kielcach, poświęcił dużo miejsca metodzie nauczania przedmiotów wykładanych w seminarium duchownym. Najwięcej uwagi skupiono na metodzie wykładu Pisma Świętego. W odniesieniu do innych przedmiotów więcej miejsca poświęcono treści wykładu, choć pojawiały się także uwagi dydaktyczne odnoszące się do ćwiczeń z danego przedmiotu. Niekiedy po wykładzie odbywała się w sekcjach dość szeroka dyskusja i w wyniku dyskusji przyjęto wiele rezolucji. Niektóre z nich mają też elementy odnoszące się do dydaktyki poszczególnych przedmiotów teologicznych.

Sekcja biblijna skupiła się na metodzie nauczania Pisma Świętego w seminarium duchownym. Referat wprowadzający przedstawił ks. A. Zawistowski z Lublina. Wykład dotyczący metody nauczania zaczął od rozróżnienia metody nauczania Pisma Świętego od metody badania Pisma Świętego. Po tym konsekwentnie omawiał metodę nauczania. Podkreślił, że w metodzie nauczania Pisma Świętego istotne są wypowiedzi Stolicy Apostolskiej. Przytoczył najważniejsze wówczas dokumenty, czyli encyklikę Leona XIII Providentissimus Deus z 1893 r. oraz motu proprio Piusa X Quoniam in re biblica z 27 marca 1906 r. Po przedstawieniu wymagań zawartych w tych dokumentach przystąpił do omówienia przedmiotów teologicznych skoncentrowanych na wykładzie Pisma Świętego. Najpierw zaakcentował znaczenie wstępu ogólnego do Pisma Święto. Podkreślił, że ma on charakter wprowadzenia do tego studium i jego przedstawienie jest ma fundamentalne znaczenie do właściwego zrozumienia treści Pisma

22 Tamże, s. 239-240.

23 Tamże, s. 244. 
Świętego. Potem omówił, jak przedstawić w tym wykładzie jego istotne elementy, czyli natchnienie Pisma Świętego, historię kanonu oraz hermeneutykę biblijną. Potem pokazał sposób przedstawienia wstępu szczegółowego do Starego i Nowego Testamentu. Omawiał też metodyczne zasady egzegezy tekstu biblijnego. Po tym przeszedł do metodyki wykładu archeologii biblijnej i języka hebrajskiego. Autor akcentował, że nauczanie tych przedmiotów powinno nie tylko pomóc poznać treść Pisma Świętego, ale też rozumieć przesłanie Biblii. To nauczanie powinno budować głębokie przekonanie i pewność odnoszącą się do nauczania Pisma Świętego. Wykład seminaryjny powinien mieć przekaz pozytywny. Po wykładzie ks. A. Zawistowskiego odbyła się dyskusja, która doprowadziła do sformułowania kilku zasadniczych wniosków. Zebrani postulowali, by teorię natchnienia przedstawianą przez teologię fundamentalną uzupełnić w ramach wstępu ogólnego do Pisma Świętego o stanowisko egzegetyczno-biblijne. W wykładzie hermeneutyki biblijnej powinno się położyć nacisk na teorię sensu biblijnego i zasady hermeneutyczne. Dalej postulowano, aby wstęp szczegółowy obejmował wszystkie księgi Pisma Świętego. Podkreślono też, że egzegeza powinna być naukowa i obejmować początkowe rozdziały Księgi Rodzaju, niektóre psalmy i proroctwa odnoszące się do Mesjasza i jego królestwa. Z Nowego Testamentu powinno się omówić Ewangelie i jeden list św. Pawła. Podkreślano też, że wykład archeologii biblijnej powinien być traktowany jak środek do lepszego rozumienia Pisma Świętego. Studium Pisma Świętego powinno być ciągłe i systematycznie uzupełniane przez jego osobistą lekturę realizowaną przez alumnów. Przyjęto też, że z poszczególnych przedmiotów tego zakresu powinny odbywać się egzaminy i od ich wyniku powinna zleżeć promocja na wyższe kursy i dopuszczenie do święceń. ${ }^{24}$

Z kolei sekcja dogmatyczno-apologoetyczna w rezolucji podkreśliła konieczność dogłębnego zapoznania alumnów z zasadami

24 A. Z a w is tow s k i, Metoda nauczania Pisma Świętego $w$ seminariach duchownych, w: ZZTwP, Pamiętnik czwartego zjazdu w Kielcach 20-22.04.1927 r., Kielce 1927, s. 127-144. 
filozofii tomistycznej oraz z metodą nauczania św. Tomasza przez czytanie odpowiednich fragmentów Summy teologicznej. ${ }^{25}$

Także sekcja prawa kanonicznego uchwaliła rezolucję odnoszącą się do nauczania prawa kanonicznego w seminariach. Podkreślono, że wskazane jest, aby to prawo wykładać w języku łacińskim z uwzględnieniem polskiej terminologii. Trzeba, aby wykład poszczególnych części kodeksu prawa kanonicznego poprzedził wstęp, zawierający wykład ogólnych norm prawnych, historii źródeł prawa kanonicznego ze szczególnym uwzględnieniem konkordatu polskiego. Przedstawiciele sekcji zaakcentowali, że żadnego działu prawa kanonicznego nie należy wyłączać z zakresu wykładów. W celu docenienia wartości polskiej tradycji religijnej zachęcano, aby w części historycznej wykładów uwzględniano dawne polskie ustawodawstwo kościelne. ${ }^{26}$

Kolejna sekcja zajmująca się historią Kościoła postulowała, aby wykłady z tego zakresu treści trwały przez trzy lata w wymiarze trzech godzin tygodniowo. Wykład powinien być żywy i obrazowy połączony z ilustrowaniem go wyjątkami ze źródeł, charakterystyką wielkich osób z historii Kościoła. Jego celem winno być rozbudzenie miłości do Kościoła i rozwijanie ciekawości dla jego działalności. Postulowano, aby jedną godzinę przeznaczyć na zajęcia o charakterze seminaryjnym. ${ }^{27}$

Także sekcja homiletyczno-patrologiczna podjęła zagadnienia metodyczne. Omówiono program nauczania a także sposób kształtowania umiejętności kaznodziejskich. Najpierw omawiano treść odnoszącą się do rozwijania dykcji a potem do teorii wymowy. $\mathrm{Na}$ kolejnym etapie analizowano dzieje i wzory wymowy. Podkreślono konieczność podręczników oraz przygotowywania wypisów kaznodziejskich, tworzenia biblioteki kaznodziejskiej, a także przygotowywanie kolektanea, czyli zbioru wypisów z literatury. Zwracano

25 Por. A. Ży c h $\mathrm{l}$ i ń s k i, O stosowaniu Summy św. Tomasza przy nauczaniu teologii dogmatycznej w seminariach duchownych, w: tamże, s. 144-166.

26 Sekcja prawno-kanoniczna, w: tamże, s. 167-170.

27 M. S k i b n i e w s k i, O warunkach pracy nad historia Kościoła, w: tamże, s. $171-179$. 
uwagę na ćwiczenia praktyczne i seminaria homiletyczne, których celem byłoby rozwijanie praktycznych umiejętności przygotowania i wygłoszenia kazania. Ukazano też potrzebę ćwiczeń pisemnym w przygotowywaniu kazań. Zwracano uwagę na potrzebę omawiania ich przez profesora wraz $\mathrm{z}$ alumnami. W trakcie roku akademickiego przez okres nauczania homiletyki każdy alumn powinien wygłosić co najmniej dwa kazania. Domagano się także krytycznego omawiania wygłoszonych kazań zarówno przez profesora jak i przez kolegów. ${ }^{28}$

Sekcja filozoficzna dyskutowała nad nauczaniem psychologii. W tamtym czasie psychologia stanowiła część filozofii. Najwięcej uwagi zajęło rozważanie, czy psychologii teoretycznej uczyć razem z psychologią eksperymentalną, czy oddzielnie. Nieco uwagi poświęcono też programowi nauczania filozofii w seminarium oraz umiejscowieniu w nim nauczania psychologii. Ustalono też, że kurs nauk filozoficznych powinien trwać dwa lata i obejmować wstęp do filozofii, logikę, krytykę, ontologie, kosmologie, psychologie, etykę, filozofię religii, teodyceę i historię filozofiii. ${ }^{29}$

Ksiądz A. Szymański na sekcji nauk społecznych omówił program i sposób nauczania socjologii. Prezentował, jak ten przedmiot jest rozumiany w poszczególnych seminariach oraz jaką przekazuje się treść w czasie jego wykładu. Prelegent zaakcentował wagę tego przedmiotu w kształtowaniu społecznych postaw duchowieństwa i przez to szansę pozytywnego oddziaływania na życie społeczne w Polsce. ${ }^{30}$

Na czwartym zjeździe Związku Zakładów Teologicznych w Kielcach powróciła też problematyka dydaktyczna w odniesieniu do przedmiotów mający bliski związek z duszpasterstwem. W wolnych wnioskach składanych na zakończenie zjazdu ks. Henryk Kaczorowski z Włocławka postulował potrzebę położenia większego nacisku

28 Z. P il c h, Program i metoda nauczania homiletyki w zakładach teologicznych, w: tamże, s. 179-207.

29 Por. P. C h oj n a c k i, Nauka psychologii w seminarium duchownym, w: tamże, s. 209-220.

30 Por. A. S z y m a ń s k i, W sprawie wykładu socjologii, w: tamże, s. 220-227. 
na nauczanie pedagogiki, dydaktyki i katechetyki w seminariach duchownych i na wydziałach teologicznych. Swój wniosek uzasadnił potrzebą lepszego przygotowania do nauczania religii w szkołach i troską o bardziej staranne wychowanie religijne w parafiach. W trakcie dyskusji podkreślono aktualność tego postulatu. Zjazd przyjął zgłoszony przez ks. H. Kaczorowskiego wniosek. ${ }^{31}$

W trakcie obrad zjazdów Związku Zakładów Teologicznych zdano sobie sprawę z potrzeby doskonalenia profesorów uczących teologii. Uświadomiono sobie, że doskonalenie dydaktyczne wykładających teologię może odbywać się przez wymianę doświadczeń w ramach Związku Zakładów Teologicznych, zwłaszcza przez udział w Zjazdach Związku Zakładów Teologicznych i w pracach poszczególnych sekcji. To doskonalenie może dotyczyć zarówno celów i zadań poszczególnych dyscyplin jak i środków i sposobów ich realizacji czy też metod naukowych poszczególnych dyscyplin. Gdy chodzi o doskonalenie w metodzie naukowej danej dyscypliny, dobrze jest przestudiować podręcznik tego przedmiotu i zastanowić się, jak przygotować wykład, aby był jasno i żywo ujęty. Profesorowie zwykle starają się przedstawić omawiane zagadnienie jak najbardziej ambitnie a nieraz nie doceniają trudności słuchaczy w zrozumieniu przedstawianej problematyki. Dlatego wykładowca dobrze powinien poznać, jakie aspekty treści przedstawianych w wykładzie sprawiają trudności słuchaczom. To może być wskazówką dla profesora, jak najprzystępniej przedstawiać problem, aby był jak najlepiej zrozumiany przez słuchaczy. ${ }^{32}$

Zjazd Zakładów Teologicznych odbywający się w Poznaniu 8-10 kwietnia 1931 r. ponownie zajął się zagadnieniami z zakresu dydaktyki. Pierwszym tematem była kwestia pracy dydaktycznej profesorów teologii. Problem przedstawił ks. Władysław Hozakowski z Poznania. Podkreślił, że każdy profesor powinien kochać przedmiot, który wykłada. To pomoże mu określić jego zakres treściowy.

\footnotetext{
31 Por. ZZTwP, Pamiętnik czwartego zjazdu w Kielcach, s. 241-242.

32 K. M a z u rki e w i z, Przygotowanie pedagogiczno-dydaktyczne profesorów teologii, s. 65-67.
} 
Powinien też umiejętnie rozłożyć materiał nauczania, zwłaszcza jeśli treść jego jest wykładana przez kilka lat, aby przekazywany materiał stanowił organiczną całość. Zamiłowanie do wykładanego przedmiotu rodzi w wykładowcy stałą chęć do nieustannego zgłębiania jego treści przez systematyczną lekturę publikacji z tego zakresu. Zamiłowanie będzie też prowadzić do głębszego poznawania treści szczegółowych. Z tym łączy się wykorzystywanie metodologii charakterystycznej dla danej dyscypliny teologicznej. Prelegent bardzo mocno podkreślił przygotowywanie wykładów w pracy dydaktycznej. Akcentował przy tym, że każdy wykład powinien być szczegółowo przemyślany i przygotowany na piśmie. Jeśli profesor korzysta z podręcznika, to sugeruje przygotowanie dyspozycji, czyli pewnego szkicu wypowiedzi. Profesor powinien też sprawdzić zrozumienie wykładu a także tam, gdzie to możliwe, prowadzić ćwiczenia służące pogłębieniu zrozumienia treści wykładu. Jeśli nie ma podręcznika, wykładowca może przekazać słuchaczom spisaną treść wykładu przed jego wygłoszeniem. Ksiądz Hozakowski zwraca też uwagę na środki służące samodzielnej pracy naukowej. Szczególnie podkreśla potrzebę gromadzenia własnej biblioteki, która obejmuje publikacje z zakresu wykładanej dyscypliny teologicznej. Profesor powinien też prowadzić samodzielną pracę naukową. Dla niej powinien też stale zbierać materiały naukowe, czy to w postaci nowych publikacji, czy wypisów. W ramach samodzielnej pracy naukowej powinno znaleźć się miejsce również na podróże naukowe. Owocem zaś prowadzonej pracy naukowej powinny stawać się nowe podręczniki, ale też artykuły naukowe. Sugeruje też, aby stworzyć dla młodszych pracowników naukowych pewien fundusz na druk prac doktorskich czy dobrych monografii. ${ }^{33}$

Drugim zagadnieniem z zakresu dydaktyki akademickiej na zjeździe w Poznaniu była problematyka sprawdzania wiedzy studentów teologii. To zagadnienie przedstawił ks. Edward Górski z Sandomierza, mówiąc o egzaminach w seminariach. Najpierw rozesłał

33 W. Ho z a kow s k i, Praca zawodowa profesorów teologii, w: ZZTwP, Pamiętnik szóstego zjazdu w Poznaniu 8-10.04.1931, Kielce 1931, s. 99-105. 
ankietę do wszystkich seminariów i na jej podstawie przedstawił, jaka jest praktyka egzaminowania, jakie są typy egzaminów i jak one przebiegają, jaki skład mają komisje egzaminacyjne, jaką posługuje się skalą ocen oraz jaka jest praktyka wystawiania ocen w seminariach. Wyniki ankiety pozwoliły stwierdzić wielką różnorodność w odniesieniu do egzaminów. Znane są egzaminy półroczne, czyli semestralne, oraz roczne. Są też kolokwia semestralne, trysemestralne, a także też egzaminy końcowe z przedmiotu wykładanego przez wiele lat, nazywane rygorozami. Liczba egzaminów w każdym niemal zakładzie jest inna. Są też egzaminy końcowe, nazywane egzaminem na absolutorium. One też miały różną formę. Obejmowały one egzamin z zasadniczych przedmiotów takich jak Pismo Święte, teologia dogmatyczna, moralna, prawo kanoniczne, liturgia i homiletyka. W Gnieźnie i Poznaniu egzamin ten ma charakter ustny i pisemny. W Bobolanum i u oo. jezuitów w Krakowie absolwent zdaje egzamin ustny z tez, które obejmują całość nauk wykładanych $\mathrm{w}$ tym seminarium. We Włocławku oprócz egzaminu $\mathrm{z}$ tez student przedstawia pracę pisemną i ma miejsce jej obrona przed komisją egzaminacyjną.

Zwykle egzaminy roczne i rygoroza odbywają się w seminariach duchownych przed komisją. W wielu seminariach w skład komisji wchodzi oprócz profesora danego przedmiotu rektor oraz jeden z profesorów w charakterze asystenta. Na przygotowanie do egzaminów rocznych i rygorozów daje się studentom od 10 dni do miesiąca. Termin egzaminów ustala rada pedagogiczna seminarium duchownego, uwzględniając często życzenia alumnów. Czas trwania odpowiedzi przed komisją waha się do kilku minut do godziny. Oceny są wystawiane według skali: celująco, bardzo dobrze, dobrze, dostatecznie i niedostatecznie. O wyniku egzaminu decyduje albo komisja, albo sam profesor. W trakcie egzaminu w kilku seminariach są wszyscy zdający z danego rocznika. W wielu jednak jest obecnych kilku. Gdy jeden z nich odpowiada inni się przygotowują do odpowiedzi.

Ta różnorodność w zakresie egzaminowania doprowadziła ks. E. Górskiego do kilku wniosków. Proponuje utrzymać egzaminy semestralne z przedmiotów zasadniczych, takich jak Pismo Święte, 
teologia dogmatyczna, moralna i prawo kanoniczne. Oprócz tego proponuje też pozostawić egzaminy roczne i kolokwia z przedmiotów drugorzędnych oraz dążyć do egzaminu na absolutorium na podstawie tez obejmujących całość zagadnień filozoficzno-teologicznych. ${ }^{34}$

Po wykładzie ks. Górskiego odbyła się intensywna dyskusja wśród uczestników zjazdu i przedstawiono dość rozbieżne wnioski. Dlatego powołano komisję w sprawie egzaminów. Ona jeszcze raz przedyskutowała problem i przedstawiła swoje rozstrzygnięcia. W swojej rezolucji zaproponowała ona, aby egzaminy półroczne z głównych przedmiotów odbywały się przed komisją. Zgodzono się też, że egzaminy końcowe powinny odbywać się na podstawie tez. Egzaminy, jej zdaniem, mogą mieć zarówno formę ustną jak i pisemną. Pisemna forma egzaminów powinna dotyczyć tylko przedmiotów głównych. Ustalono też wnioski mniejszości. Wśród nich był postulat, aby zrezygnować z kontroli na egzaminach z poszczególnych wykładów. Kontrola egzaminacyjna powinna odbywać się bez uroczystego aparatu, czyli bez udziału komisji lecz tylko w obecności profesora. Niedostateczna ocena z jakiegoś przedmiotu wymaga ponownego egzaminu przed komisją. $Z$ głównych egzaminów na zakończenie cyklu wykładów, czyli z filozofii, historii Kościoła, dogmatyki, teologii moralnej, Pisma Świętego i prawa kanonicznego, proponuje się egzamin przed komisją. ${ }^{35}$

Na zjeździe w Wilnie w 1933 r. powrócono do zagadnień dydaktycznych. Ksiądz Julian Piskorz z Tarnowa podjął zagadnienie $Z$ dydaktyki teologii: metoda wyktadu. W jednym z pierwszych przypisów do referatu zdradza, że w środowisku seminarium duchownego w Tarnowie profesorowie omawiali problematykę dydaktyczną przez cały rok w okresie między zjazdami Związku Zakładów Teologicznych w odniesieniu do nauczania teologii na spotkaniach Tarnowskiego Koła Profesorów Teologii. Dlatego też autor przytacza dość obszerną literaturę z zakresu dydaktyki akademickiej. Opatrzył te

34 E. Gó r s k i, Sprawa egzaminów w naszych zakładach teologicznych, $\mathrm{w}$ : tamże, s. 105-113.

35 Tamże, s. 113-115. 
publikacje swoim krytycznym komentarzem. Wyraża też nadzieję, że będzie to jakimś elementem wspomagającym przygotowanie podręcznika akademickiej dydaktyki teologii. ${ }^{36}$

Jego zdaniem, przy omawianiu metody wykładu akademickiego trzeba przyjąć najpierw pewne zastrzeżenia. Pierwsze z nich to, że celem wykładu na poziomie akademickim jest naukowe zgłębianie wiedzy. Nauczanie akademickie nie musi już tak bardzo dbać o umysłowy rozwój wychowanka, jak to jest w szkole średniej, bo ma już do czynienia z osobą dojrzała w tym zakresie. Cechą tego wykładu jest też wolność akademicka wykluczająca przymus programów i metod i przymus rygoru szkolnego. ${ }^{37}$

Podkreśla też, że wykładowca powinien mieć pewne wrodzone, naturalne zdolności. W życiu akademickim spotyka się albo bardzo wybitne jednostki, albo bardzo słabe w dziedzinie dydaktyki. Pozostali są raczej przeciętnymi wykładowcami. Dlatego przede wszystkim oni potrzebują pewnej wiedzy metodycznej. Tak więc wykład akademicki powinien przede wszystkim przedstawić prawdę. Ma on ułatwić słuchaczowi jej poznanie. Nie może być zapisem poszukiwań naukowych profesora, raczej powinien być prezentacją uzyskanych i uporządkowanych już wyników naukowych. Aby w sposób poprawny przygotować wykład, trzeba mieć świadomość, że zdobywanie wiedzy odpowiada określonym stadiom psychicznym. Do zasadniczych należy poznanie prawdy. Następnym etapem jest zrozumienie prawdy. Kolejnym zaś krokiem jest zainteresowanie się prawdą, a ostatnim etapem jest zamiłowanie obejmujące miłość a nawet ofiarne oddanie się uznawanej prawdzie. W wykładzie ważne jest utrzymanie uwagi dowolnej słuchacza. Temu służy przede wszystkim dobre opanowanie treści i przedstawianie treści wykładu raczej z pamięci, a nie czytanie gotowego wykładu czy treści z podręcznika. W trakcie wykładu autor radzi, aby wykładowca nie opuszczał katedry i nie chodził po klasie, oraz nie gestykulował nadmiernie.

36 J. P i s k o r z, Z dydaktyki teologii, w: ZZTwP, Pamiętnik siódmego zjazdu odbytego w Wilnie 19-21.04.1933, s. 53-54.

37 Tamże, s. 54-55. 
Takie zachowanie wykładowcy, jego zdaniem, może rozpraszać słuchacza. Wykład trzeba też prowadzić dość głośno, aby słuchacz bez wysiłku zrozumiał jego treść. Jego odbiór ułatwia także właściwe akcentowanie poszczególnych wyrażeń czy jakichś fraz wypowiedzi. Istotne jest trzymanie się w wykładzie logicznego porządku. To pogłębia jego zrozumienie. Ponadto ważne jest mówienie w tempie, które umożliwia słuchaczom zrobienie notatek z wykładu. Wykład nie może jednak przekształcić się $\mathrm{w}$ dyktando. ${ }^{38}$ Kolejnym etapem jest zrozumienie. Zrozumienie może być pełne albo częściowe. To zależy też od słuchacza. Przede wszystkim uwarunkowane jest zdolnościami umysłowymi studenta, jego uwagą, zainteresowaniami i zamiłowaniami. Profesor powinien zrobić wszystko, aby umożliwić zrozumienie. Dlatego pewną pomocą może być poglądowość, ale nie jest to naczelna zasada dydaktyki na tym poziomie. Akcentuje na tym etapie potrzebę dokładnego wyjaśnienia pojęć i zakresu treści. Zrozumienie ułatwia zapowiedź struktury wykładu i jej przypominanie w trakcie przechodzenia od jednego punktu do następnego. Radzi też precyzyjne rozczłonkować szczegółowe kwestie, ale istotne jest też zaakcentowanie połączenia logicznego z poprzednimi i kolejnymi elementami przedstawianej treści. ${ }^{39}$

Kolejnym elementem w metodzie wykładu jest zainteresowanie. Rozumie on je jako pewną skłonność do działania. Zainteresowanie naukowe jest nastawieniem aktywnym wszystkich zdolności psychicznych na przedmiot naukowy. Objawia się ono zazwyczaj natężoną uwagą, pociągiem do danego przedmiotu i czerpaniem przyjemności z jego poznania. Stałe zainteresowanie poznawaną treścią należałoby nazwać zamiłowaniem. Zainteresowanie ma różne stopnie - od słabego zainteresowania aż do zamiłowania. Jest ono istotne przy zdobywaniu wiedzy. Ono wpływa na uwagę poznającego, wyostrza ją i utrzymuje w napięciu. Zainteresowanie wprowadza wolę w stan aktywny. Wola jest przyczyną wytrwałości, cierpliwości i efektywności w studiowaniu. Autor wykładu podkreśla,

38 Tamże, s. 58-65.

39 Tamże, s. 65-72. 
że rozbudzeniu zainteresowań studenta sprzyjają zainteresowanie i zamiłowanie profesora. Dlatego wykładowca powinien przejawiać zamiłowanie do wykładanego przedmiotu. ${ }^{40}$

W wykładzie, zdaniem ks. Juliana Piskorza, trzeba dążyć do rozbudzenia zamiłowania do przedstawianej prawdy. Jest ono statecznym celem wykładów. W teologii chodzi przede wszystkim o rozbudzanie zamiłowania do chrześcijaństwa. Zainteresowanie jest zazwyczaj chwilowe, a zamiłowanie trwałe. Oznacza ono silne przekonanie o prawdzie poznawanej wiedzy teologicznej. Stopniowo pojawia się głębokie przekonanie i silna wiara. Opierając się na tej wierze, stopniowo kształtuje się światopogląd. Wiedza religijna powinna przeniknąć do głębi osobowość i przekształcić uczucia, dążenia i wolę. Religijny światopogląd sprawia, że człowiek patrzy na wszystkie sprawy z punktu widzenia wiary. Głębokie przekonanie wywołane przez światopogląd pociąga za sobą uczucie najwyższego szacunku i czci dla prawd Bożych. Za przekonaniami podąża wola, czyli chęć poświęcenia życia dla tych ideałów. To poświęcenie motywuje również do dzielenia się z innymi poznaną prawdą, czyli nauczania innych. ${ }^{41}$

Ksiądz Julian Piskorz proponuje, aby omówić w przyszłości kolejne tematy z dydaktyki teologii. Wśród nich wymienia sposób nauczania teologii w odniesieniu do nowoczesnych teorii dydaktycznych, czy zagadnienia takie jak socjologia czy psychologia nauczania teologii a także cechy profesora teologii oraz wartości wychowawcze poszczególnych przedmiotów teologicznych. ${ }^{42}$ Można więc przypuszczać, że namysł nad dydaktyką teologii w środowisku tarnowskim był dość głęboki. Sam przekrój proponowanych do omówienia tematów sugeruje niemal projekt podręcznika dydaktyki akademickiej dla teologii.

Problematyka dydaktyki teologii w odniesieniu do nauczania katechetyki pojawiła się także na sekcji pedagogiczno-katechetycznej w trakcie zjazdu w Wilnie. Najpierw ks. Michał Sopoćko z Wydziału

\footnotetext{
40 Tamże, s. 72-83.

${ }^{41}$ Tamże, s. 83-85.

42 Tamże, s. 85.
} 
Teologicznego w Wilnie przedstawił wykład Program katechetyki w seminariach duchownych. W drugiej części spotkania w tej sekcji ks. Karol Mazurkiewicz omówił Zagadnienia hodegetyczne na naszych katedrach. Program wykładów katechetycznych był już obecny na pierwszym zjeździe Związku Zakładów Teologicznych we Włocławku. Wówczas podzielono się przede wszystkim stanem nauczania katechetyki w seminariach. To zagadnienie przedstawił ks. Stanisław Krzeszkiewicz z Gniezna. ${ }^{43}$ Obecnie ks. Michał Sopoćko akcentował potrzebę prowadzenia wykładów i ćwiczeń z katechetyki. Z przeprowadzonej przez niego ogólnopolskiej ankiety w seminariach duchownych wynika, że w niektórych seminariach jeszcze nie uczy się katechetyki, a w innych przeznacza się na nią tylko jedną godzinę. Tymczasem konieczność wykładania katechetyki wynika z kilku względów. Katechetyka powinna być przedmiotem ważnym, który przygotuje do nauczania lekcji religii w szkole. Aby nauczanie religii było owocne a nauczyciele mieli autorytet, muszą otrzymać odpowiednie przygotowanie do nauczania religii zarówno z dydaktyki jak też z teorii katechezy. Przypominał, że władze duchowne są zobowiązane do wprowadzenia tego przedmiotu Kodeksem prawa kanonicznego i pismami prefekta kongregacji seminariów i uniwersytetów z roku 1926, 1929 i 1931. Prefekt tej Kongregacji podkreśla, że w seminariach należy wykładać katechetykę jako przedmiot osobny, oddzielony od teologii pastoralnej i pedagogiki. ${ }^{44}$

Ksiądz Michał Sopoćko proponuje, aby umieścić katechetykę (teoria katechetyczna) na pierwszym roku teologii, to znaczy na trzecim roku studiów teologicznych oraz na czwartym i piątym roku teologii (ćwiczenia katechetyczne). Proponuje też, aby przygotowaniem do wykładania katechetyki było nauczanie pedagogiki na drugim roku. Zaś na ostatnim roku proponuje pedagogikę praktyczną. Wykłady

43 S. K r ze s z k i e w i c z, Sprawa prowadzenia katechetyki w seminariach duchownych, w. ZZTwP, Pamiętnik pierwszego zjazdu odbytego we Włocławku 30.10-01.11.1921 r., Włocławek 1922, s. 101-105.

44 M. S o p o ć k o, Program katechetyki w seminariach duchownych, w: ZZTwP, Pamiętnik siódmego zjazdu w Wilnie, s. 309-315. 
z pedagogiki powinny objąć definicję katechetyki, zadania katechetyki, historię katechetyki, dydaktykę ogólną, metodykę religii oraz treści charakteryzujące osobowość katechety. Dział odnoszący się do osobowości może zostać zrealizowany wówczas, gdy są na to warunki. Osobowość wychowawcy jest też omawiana na wykładach z pedagogiki. Ksiądz Sopocko akcentuje też wielką wagę ćwiczeń katechetycznych. Podkreśla, że każdy kleryk powinien przeprowadzić choćby jedną lekcję i powinna być ona hospitowana przez profesora katechetyki i kolegów, a potem krytycznie omówiona. ${ }^{45}$

Autor odnosi się też do pomocy do wykładu katechetyki. Dzięki jego wypowiedzi wiemy, że funkcjonowało kilka podręczników do katechetyki ${ }^{46}$ były też podejmowane wysiłki stworzenia kolejnych. Sam autor zdradza zamiar przygotowania podręcznika. Jednak uprzedził go ks. Bielawski. ${ }^{47}$ Podręcznik ks. Bielawskiego odpowiada układowi treści proponowanemu przez ks. Michała Sopoćkę. Dlatego autor oświadcza w trakcie wykładu, że rezygnuje z przygotowania własnego podręcznika o bardzo podobnym układzie treści do podręcznika ks. Bielawski. Ksiądz Sopoćko podkreśla, że znane były i wykorzystywane przez wykładowców katechetyki także podręczniki obcojęzyczne, zwłaszcza z kręgu języka niemieckiego. ${ }^{48}$

Na zjeździe w Wilnie w 1933 r. sekcja pedagogiczno-katechetyczna podjęła bardzo istotną rezolucję. Była ona skierowana przede wszystkim do biskupów polskich. Sekcja zwracała się do biskupów o utworzenie katolickiego studium pedagogicznego w Polsce w celu kształcenia pedagogicznego zarówno kapłanów jak i świeckich,

45 Tamże, s. 315-318.

46 W. K o s i ń s k i, Katechetyka, Sandomierz 1929; t e n ż e, Dydaktyka, Sandomierz 1924; S. K r z e s z k i e w i c z, Metodyka nauki religii, Poznań 1926; F. S p i r a g o, Metodyka katolickiej nauki religii, Mikołów 1922, J. B o c z a r, Metodyka nauczania religii katolickiej, Poznań 1931.

47 Por. Z. B i e l a w s k i, Pedagogika religijno-moralna, Lwów 1934.

48 H. M a y e r, Katechetik, Freiburg 1924; J. G o $t$ t 1 e r, Religions und Moralpädagogik, Münster 1931; M. G a t t e r e r, Katechetik oder Anleitung zur Kinderseelsorge, Innsbruk 1931; C. K ri e g, Katechetik oder Wissenschaft vom kirchlichen Katechumenate, Feiburg im Br. 1907. 
a także o wysyłanie młodych kapłanów na studia pedagogiczne celem przygotowania profesorów katechetyki i wizytatorów nauki religii oraz o ustalenie programu przedmiotów pedagogicznych w seminariach duchownych oraz o wyznaczenie im miejsca w siatce godzin w planie seminaryjnym. W tej rezolucji podkreślali też, że w celu przygotowania pedagogiczno-katechetycznego alumna konieczne jest 6-7 godzin pedagogiki tygodniowo w planie rocznym. ${ }^{49}$ Ten apel jest wyrazem bardzo dużej potrzeby kształcenia pedagogiczno-katechetycznego w seminariach duchownych i na wydziałach teologicznych.

$* * *$

Zjazdy Związku Zakładów Teologicznych okresie międzywojennym spełniły swoją rolę w zakresie budzenia zainteresowania wykładowców teologii problematyką pedagogiczną oraz dydaktyczną. Dzięki podejmowanym wysiłkom doszło do znacznego ujednolicenia struktury studiów i jego treści. Uświadomiono sobie wagę przedmiotów pedagogicznych i katechetycznych w procesie kształcenia seminaryjnego. Podejmowano wysiłki wypracowania polskiej terminologii teologicznej, dokonano krytycznej oceny treści nauczonych przedmiotów oraz przeglądu używanych podręczników. Z upływem czasu w wielu dziedzinach teologii przystąpiono do przyswojenia treści teologicznych przez tłumaczenie najlepszych podręczników, a potem do pisania polskich podręczników teologicznych. Powstały też podręczniki do nauczania pedagogiki na wydziałach teologicznych, napisane przez polskich wykładowców, oraz podręczniki do nauczania katechetyki. Stopniowo pogłębiała się problematyka z zakresu dydaktyki szkoły wyższej. Refleksja pedagogiczna i dydaktyczna była podejmowana przez członków Związku Zakładów Teologicznych w organie Związku, jakim było czasopismo teologiczne „Ateneum Kapłańskie”. Na jego łamach publikowali J. Świrski, S. Wyszyński, A. Poszwa, P. Tochowicz, W. Granat, Wójcicki, Weryński. Podejmowana refleksja nad zagadnieniami pedagogicznymi była formą

49 M. S o p o ć k o, Program katechetyki w seminariach duchownych, s. 321. 
doskonalenia zawodowego wykładowców teologii oraz przyczyniła się do zapewne do udoskonalenia pracy pedagogicznej absolwentów wydziałów teologicznych w czasie nauczania lekcji religii. Miało to wielkie znaczenie w podniesieniu poziomu kształcenia przyszłych księży, mających się stać nauczycielami religii w różnych typach szkół. Znakiem uznania przez państwo polskie dla wysokiego poziomu kształcenia w seminariach duchownych była decyzja Ministerstwa Wyznań i Oświecenia Publicznego, uznająca kształcenie w Wyższym Seminarium Duchownym we Włocławku na poziomie akademickim. ${ }^{50}$

ks. Kazimierz SKOCZYLAS

Słowa kluczowe: teologia; pedagogika; dydaktyka; dydaktyka szkoły wyższej; katechetyka; metodyka nauczania

Keywords: theology; pedagogy; didactics; didactics of a high school; catechetics; teaching methodology

\section{Pedagogical issues as an element of improving theology teachers in Poland in the years 1918-1939 \\ Summary}

Pedagogical issues were present in senior seminaries in Poland in the interwar period. The interest in this subject was inspired by Jan Kanty Association of Theological Schools. The members of this association were lecturers of various theological subjects of higher seminaries and theological faculties in Poland. The Association discussed both pedagogical and didactic problems. The teaching contents of particular subjects, the teaching methods, textbooks as well as ways to familiarize students of theology with pedagogical issues were discussed by it.

50 Por. Rozporzadzenie Rady Ministrów z dnia 8 XI 1929 r. o zakładach naukowych i egzaminach szkolnych wystarczajacych do osiagnięcia stanowiska urzędniczego w państwowej stużbie cywilnej, Dz. U. 1929 Nr 88, poz. 663. 